\title{
Herbal Bio-Disinfectants: Z. zanthoxyloides and G. latifolium as Effective Antimicrobial Agents against Inherent Microbial Pathogens in Water.
}

\author{
A.O ADEEYO ${ }^{1,3^{*}}$, J.O ODIYO $^{2}$, T.A.M MSAGATI ${ }^{3}$
}

${ }^{1}$ Department of Ecology and Resource Management, University of Venda, Private Bag X5050, Thohoyandou (0950) South Africa.

${ }^{2}$ Hydrology and Water Resources, University of Venda, Private Bag X5050, Thohoyandou (0950) South Africa. ${ }^{3}$ Nanotechnology and Water Sustainability Research Unit, Private Bag X6, Roodepoort, University of South Africa, Johanesburg, South Africa (1705)

\begin{abstract}
Water and sanitation facilities in sub-Saharan Africa and Africa in general are appalling and for the most part absent. Progress continues with respect to the development of plant materials as potent adsorbents, disinfectants, coagulants, flocculants, wetland species and lots more as substitutes for the dangerous chemical disinfectants.

This research presents the potential of phyto-active components of Zanthoxylum zanthoxyloides and Gongronema latifolium as effective biocides against water microbial contaminants. Dry powder of Zanthoxylum zanthoxyloides and Gongronema latifolium were extracted and prepared into different concentrations with ethyl acetate and chloroform, ranging from 25 to $500 \mathrm{mg} / \mathrm{ml}$. These fractions were then examined for antimicrobial activities against inherent bacterial and fungal water contaminants using disc diffusion assay. Fractions were afterwards screened for phytochemical active compounds using standard methods. Crude extracts of the different plant examined selectively comprise saponins, tannins, reducing sugars, anthraquinones, flavonoids, terpenoids, phlobatanins and alkaloids. All plant extracts showed broad spectrum antibiosis against selected gram positive and gram negative bacteria including E. coli, $P$. aeruginosa, Klebsiella sp, S. pneumoniae and B. cereus, as well as tested fungi, including $A$. niger, A. flavus, Trichoderma sp and Candida sp. While all extracts exhibited maximum antibiosis at $500 \mathrm{mg} / \mathrm{ml}$, the chloroform extracts compared well than ethyl acetate extracts. The overall results revealed that antimicrobial activities of the plant extracts are dose dependent with comparative activity greater than that of commercial antibiotics at the concentration of extracts tested. E.coli was the most susceptible microbial isolate tested and represents the potential of the extract against a group of coliform which are important indicators of microbial pollution in water. Other microbial isolates also recorded sensitivity to extracts tested at varying degrees. The findings indicate that microbes tested were mostly susceptible to chloroform extract of $Z$. zanthoxyloides and G. latifolium except for the activity of ethyl acetate extract of Z. zanthoxyloide against E.coli. Results of phytochemical screening of the extract also showed the varied presence of alkaloids, saponins, tannins, flavonoids, terpenoids and anthraquinones The results indicated that plant materials investigated can be developed as effective biocides against water microbial contaminants.
\end{abstract}

Key words: Bio-disinfection; G. latifolium; Wate; Z. zanthoxyloides.

\section{Introduction}

Drinking water is a basic human need [1]. Access to safe water is considered a fundamental human right and individuals are entitlement to sufficient, safe, accessible and affordable water without discrimination [2,3]. Human settlement, civilisation and religion have all evolved round water [4]. The importance of water as source of life and purification is well inscribed in history; Hindus, sprinkle water on new born child and believed that "The iota of life is created in water" (Hinduism: Atharvaveda, Asthagarideyam); Muslims feed on a drop of "zam zam" holy water from Mecca and hold the view that "By means of water, God gives life to every living thing" (Islam: Quran 21:30); Christians perform baptism and water is usually a fundamental symbol of faith, "Whoever believes in me, stream of living water will pour from within him" (Christianity: John 7:38). Excavations from the Neolithic time have found a striking correspondence between settlements and wells [3]. The importance of ample water and quality is thus apparent in human history and beliefs [4]. The Biblical book of Exodus (15:23-27) is the earliest historical reference to phyto-purification of water; "And the people murmured against Moses, saying, "What shall we drink?" And he cried unto the Lord; and the Lord showed him a tree, which when he had cast into the waters, the waters were made sweet" [4]. 
Water treatment involves the processing of raw water to improve its quality to meet prescribed standards for domestic, industrial and commercial uses. It is strategically employed to prevent the ingestion of harmful contaminants [5]. However, water processing in disinfection units is not utilised fully in developing countries because of cost issues associated with the procurement and import of disinfecting chemicals. This has resulted to increased vulnerability of many rural communities in developing African countries to waterborne diseases and death [1,6-8]. Children and the elderly are mainly affected [9]. It has been recommended that household water treatment techniques [10], is a way forward to combatting drinking water problems [11]. The quest to meet the enormous water challenges of the developing countries at the household level have led to growing interest in plant-based water treatment solutions (Table 1). However, there is little information regarding the use of natural extracts as disinfectants in water treatment. With Africa having good percentage of medicinal plants [1], it is important to understand the potential of African indigenous plant extracts in water treatment, especially their antimicrobial properties. Two important locally available plants found in many African countries worthy of further investigation are Zanthoxylum zanthoxyloides and Gongronema latifolium [8].

Zanthoxylum are deciduous shrubs and trees of the family Rutaceae which comprise 250 species used as sources of pharmaceutical and cosmetics raw materials. Traditionally, leaves and fruits are used for mouth freshing and tooth care [12,13]. Zanthoxylum zanthoxyloides is considered antiseptic, analgesic and diaphoretic, used in treatment of malaria, fever, sickle cell anaemia, tuberculosis, paralysis, oedema and general body weakness. It is taken to treat intestinal problems, including colic, dysentery, intestinal worms, gonorrhoea and urethritis, but also to treat pain during childbirth, migraine and neuralgia. The roots are externally applied to ulcers, swellings, haemorrhoids, abscesses, snake bites, yaws, wounds leprosy and syphilitic sores as well as rheumatic and arthritic pain and hernia [14]. The roots and stem are widely used in the treatment of sore gums, toothache and dental caries. A decoction of the roots is used as a mouthwash and against a sore throat. Sap from the pulped bark is applied as eye drops to treat eye infections, notably conjunctivitis with pus. Root and stem bark powder is taken to treat whooping cough [15]. In southern Nigeria a decoction of the stem bark and roots is taken to treat cancer. Z. zanthoxyloides also has numerous magico-religious uses, including protection against spirits. It also serves as fetish plant [15]. Diverse phytochemicals have been reported as constituents of the plants [16-19].

Gongronema latifolium (Asclapiadaceae) is a perennial edible plant with soft and pliable stem [20]. Reports by various authors showed that it contains essential oils, saponins, alkaloids and tannins among others [21-24]. Aqueous and ethanolic G. latifolium extracts had hypoglycemic, hypolipidemic, antioxidative and antiinflammatory properties [23,25-27]. Infusion of the aerial parts is taken to treat cough, intestinal worms, dysentery, and malaria. It is also taken as a tonic to treat loss of appetite. In Sierra Leone an infusion or decoction of the stems with lime juice is taken as a purge to treat colic and stomach-ache. In Senegal and Ghana the leaves are rubbed on the joints of small children to help them walk. The boiled fruits in soup are eaten as laxative [28]. Decoction of leaves or leafy stems is commonly taken to treat diabetes and high blood pressure. The latex is applied to teeth affected by caries. It is also taken for controlling weight gain in lactating women and overall health management. Asthma patients chew fresh leaves to relieve wheezing. A cold maceration of the roots is also taken as remedy for asthma. A decoction of the roots, combined with other plant species, is taken to treat sickle cell anaemia. A maceration of the leaves in alcohol is taken to treat bilharziosis, viralhepatitis and as a general antimicrobial agent [29]. Several 17 $\beta$-marsdenin derivatives (pregnane glycosides), as well as $\beta$-sitosterol, lupenylcinnamate, lupenyl acetate, lupeol, essential oils and saponins have been found in the plant. The essential oil from the leaves contains as main components linalool (19.5\%), (E)phytol (15.3\%) and aroma dendrene hydrate (9.8\%) [30,31]. 
Table 1. List of plant species used as coagulants and disinfectants.

\begin{tabular}{|c|c|c|c|c|c|c|}
\hline Scientific name & Family & Genera & Plant part: & Habit & Reference & Uses \\
\hline Moringa oleifera Lam. & Moringaceae & Moringa & Seed & Tree & {$[32]$} & Coagulation and \\
\hline Opuntia ficus indica (L.) Mill. & Cactaceae & Opuntia & Leaves & Shrub & [34] & Coagulation and \\
\hline & & & & & & disinfection \\
\hline Cicer arietinum $\mathrm{L}$. & Fabaceae & Cicer & Seeds & Herb & {$[36]$} & $\begin{array}{l}\text { Coagulation and } \\
\text { disinfection }\end{array}$ \\
\hline Aloe barbadensis Mill. & Alloaceae & Aloe & Seeds & Herb & & \\
\hline Hibiscus sabdarifa $\mathrm{L}$. & Malvaceae & Hibiscus & Calyx & Herb & {$[37,38]$} & \\
\hline Jatropha curcas L. & Euphorbiaceae & Jatropha & Seed & Tree & & \\
\hline Parkinsonia aculeata L; & Fabaceae & Parkinsonia & Seed & Tree & [39] & $\begin{array}{l}\text { Coagulation and } \\
\text { disinfection }\end{array}$ \\
\hline Vigna unguiculata (L.) & Fabaceae & Vigna & Seed & Herb & & \\
\hline Cyamopsis tetragono & Fabaceae & Cyamopsis & Seed & Herb & [40] & $\begin{array}{l}\text { Coagulation and } \\
\text { disinfection }\end{array}$ \\
\hline Manihot esculenta crantz & Euphorbiaceae & Manihot & Root & Shrub & [41] & $\begin{array}{l}\text { Coagulation and } \\
\text { disinfection }\end{array}$ \\
\hline Solanum incunum L. & Solanaceae & Solanum & Leaf & Shrub & [42] & $\begin{array}{l}\text { Coagulation and } \\
\text { disinfection }\end{array}$ \\
\hline Phaseolus vulgaris $\mathrm{L}$. & Fabaceae & Phaseolus & Seed & Herb & [43] & Coagulation \\
\hline
\end{tabular}

The aim of the work reported in this paper was to assess the antimicrobial effects of stem extracts from the two selected plants on inherent bacterial and fungal water contaminants as a means of investigating their use as disinfectants in developing countries where access to clean water is a big challenge.

\section{Materials and Methods}

\subsection{Sampling}

Zanthoxylum zanthoxyloides and Gongronema latifolium samples were collected from Oja Igbo market at Ogbomoso North local government, Oyo State. The samples were washed, air dried and grounded to powder, then sieved to get a fine powder.

\subsection{Preparation of samples}

$50 \mathrm{~g}$ of dried and grounded samples of Zanthoxylum zanthoxyloides and Gongronema latifolium were extracted separately by maceration using $150 \mathrm{ml}$ of ethyl acetate and chloroform as extraction solvent for 48 hours. The solvents fractions were separated using vacuum filtration aided by a sterile Whatmann No 1 filter paper and filtering crucible. The filtered extract were then dried with the help of a freeze drier and stored in sterile polypropylene airtight container at $4{ }^{\circ} \mathrm{C}$ or dispensed in appropriate sterile dissolving solution when required.

\subsection{Antimicrobial Activity}

\subsubsection{Preparation of antimicrobial disc and sensitivity test}

Different concentrations of crude extracts of G. latifolium and Z. Zanthoxyloides ranging between 25 and 500 $\mathrm{mg} / \mathrm{ml}$ were prepared by dissolving appropriate amount of crystalised extracts into ethyl acetate or chloroform. Solutions were then embedded in $6.0 \mathrm{~mm}$ diameter sterile disc prior to antimicrobial sensitivity testing by disc diffusion method as described by [44]. Briefly, the test organism was swabbed evenly on the surface of the agar plate using surface spread method. Impregnated paper discs with different concentrations of crude extracts were then arranged serially and radially, and pressed slightly but firmly to the surface of inoculated agar. The plates were afterward incubated at $37^{\circ} \mathrm{C}$ for 24 hours. The fungi plates were incubated at room temperature $(27 \pm 2$ ${ }^{\circ} \mathrm{C}$ ) for 48 hours. The degree of sensitivity was determined by measuring the diameter in millimeter of the visible zone of inhibition of microbial growth produced by the diffusion of the extract. Test concentrations of crude extract were $500 \mathrm{mg} / \mathrm{ml}, 250 \mathrm{mg} / \mathrm{ml}, 100 \mathrm{mg} / \mathrm{ml}, 50 \mathrm{mg} / \mathrm{ml}$ and $25 \mathrm{mg} / \mathrm{ml}$. Standard reference commercial 
antibiotics disc for gram negative (streptomycin), gram positive (gentamycin) and the fungi (nystatin) were used for a comparative study.

\subsection{Phytochemical analyses}

The phytochemical screening of the extracts was investigated according to standard methods and as modified by Harborne [45] and Adeeyo et al. [46]. Screening for tannins, saponnin, reducing sugars, alkaloids, terpenoids, flavonoids, steroids, anthraquinones and phlobatannins were carried out on extracted crude products.

\subsection{Data Analysis}

The Statistical Package for Social Scientists (SPSS, version 19.0) was used for the analysis of the data obtained. Two way ANOVA test was used to determine the level of significance of the crude extracts at different concentration. Also, comparison of the different solvent extraction (ethyl acetate and chloroform) was made statistically, the general antimicrobial effects of the extracts were compared with the standard antibiotics. Zones of inhibition was compared with reference standard to assign the level of activities of extracts.

\section{Result and discussion}

The antimicrobial activities of extracted phytobiotics against bacterial and fungal isolates tested were investigated with extract doses ranging from $25-500 \mathrm{mg} / \mathrm{ml}$. Figure 1 shows the zone of inhibition of $G$. latifolium and Z. zanthzyloides against selected gram negative ( $P$. aeruginosa, Klebsiella sp., E. coli), gram positive (S. pneumonia, B. cereus) and Table 2 shows the inhibition of the plant materials against fungal isolates (A. flavus, A. niger, Trichoderma sp and Candida sp.) using ethyl acetate and chloroform as extraction solvents. 
A

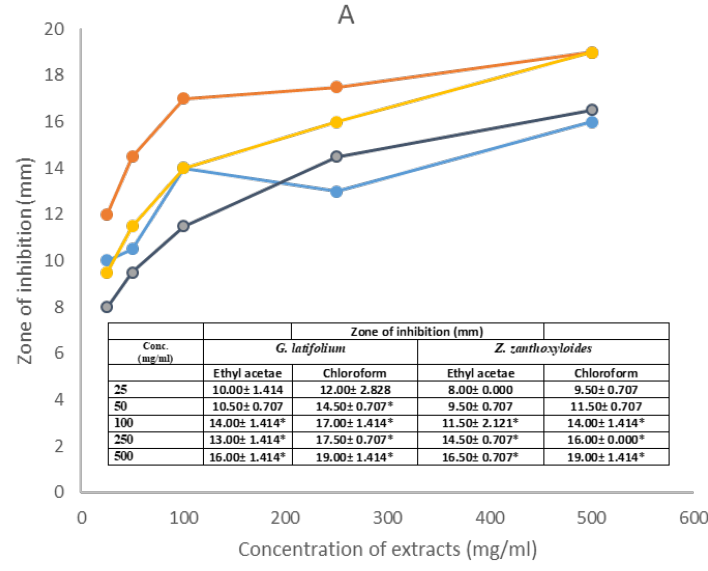

$\rightarrow$ Ge $\rightarrow$ Gc $\multimap-\mathrm{Ze} \multimap-\mathrm{Zc}$

C

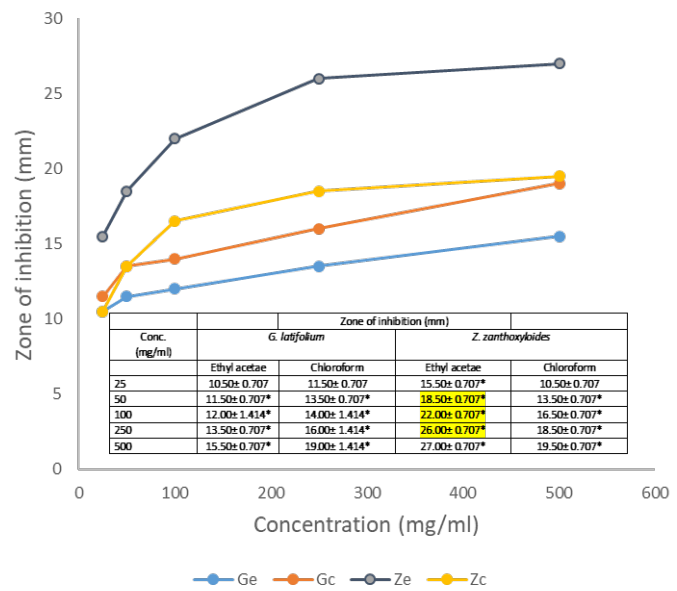

B

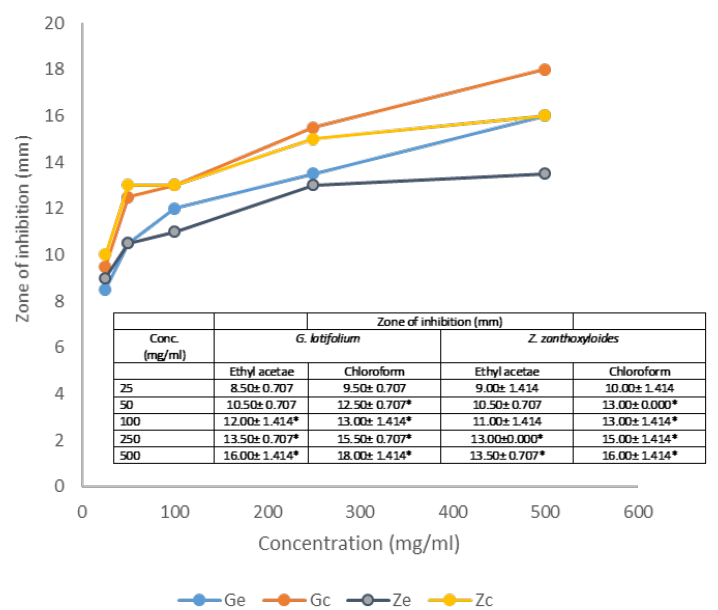

D

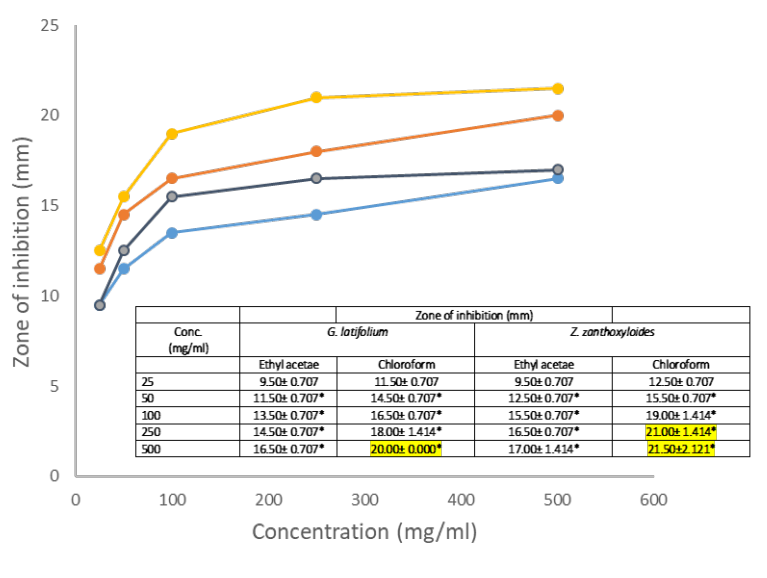

$\multimap G e-G c \multimap Z-Z$ Ze

E

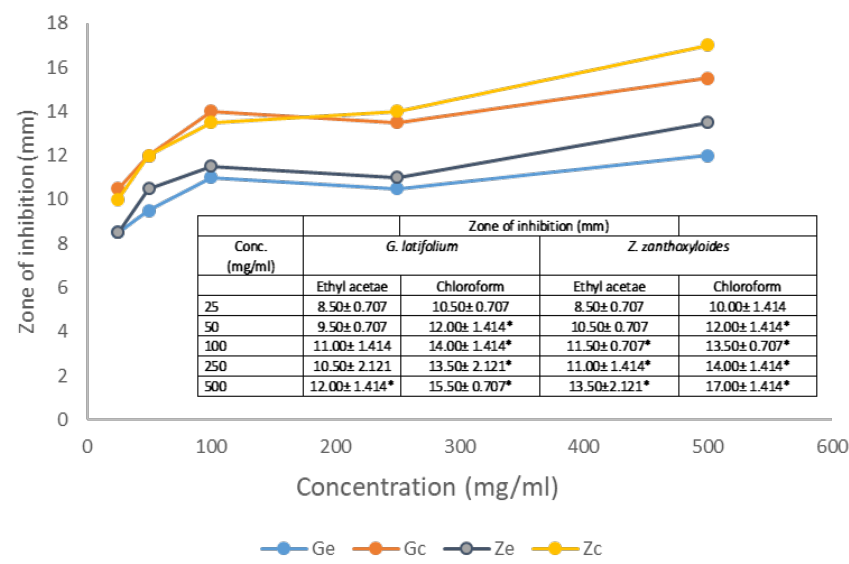

Figure 1: Antibacterial activities of G. latifolium and Z. zanthoxyloides Chloroform and Ethyl acetate extract on (A) P. aeruginosa, (B) Klebsiella sp, (C) E. coli, (D) S. pneumonia and (E) B. cereus. Inset values of inhibitions with significant difference. Extracts: Ge, Gongronema ethyl acetate; Gc, Gongronema chloroform; Ze, Zanthoxylum ethyl acetate; Zc, Zanthoxylum chloroform. 
Table 2: Antifungal activities of G. latifolium and Z. zanthoxyloides

\begin{tabular}{|c|c|c|}
\hline $\begin{array}{l}\text { Conc. } \\
\mathrm{mg} / \mathrm{ml}\end{array}$ & Ethyl acetate & Chloroform \\
\hline \multicolumn{3}{|c|}{ A. flavus } \\
\hline 25 & $7.50 \pm 0.707$ & $9.50 \pm 0.707$ \\
\hline 50 & $9.50 \pm 0.707$ & $11.50 \pm 0.707^{*}$ \\
\hline 100 & $10.50 \pm 0.707$ & $13.50 \pm 0.707^{*}$ \\
\hline 250 & $12.50 \pm 0.707^{*}$ & $15.00 \pm 0.000^{*}$ \\
\hline 500 & $11.00 \pm 1.414^{*}$ & $12.50 \pm 2.121^{*}$ \\
\hline \multicolumn{3}{|c|}{ A. niger } \\
\hline 25 & $9.50 \pm 0.707$ & $11.00 \pm 1.414$ \\
\hline 50 & $9.00 \pm 1.414$ & $11.50 \pm 2.121$ \\
\hline 100 & $11.00 \pm 1.414$ & $13.50 \pm 0.707 *$ \\
\hline 250 & $11.50 \pm 2.121$ & $14.00 \pm 1.414^{*}$ \\
\hline 500 & $14.50 \pm 0.707^{*}$ & $17.00 \pm 1.414^{*}$ \\
\hline \multicolumn{3}{|c|}{ Trichoderma sp } \\
\hline 25 & $8.50 \pm 0.707$ & $11.00 \pm 1.414$ \\
\hline 50 & $10.50 \pm 0.707$ & $14.00 \pm 1.414^{*}$ \\
\hline 100 & $12.00 \pm 1.414^{*}$ & $15.50 \pm 0.707^{*}$ \\
\hline 250 & $13.50 \pm 0.707^{*}$ & $16.50 \pm 0.707^{*}$ \\
\hline 500 & $13.50 \pm 0.707 *$ & $18.50 \pm 0.707^{*}$ \\
\hline \multicolumn{3}{|c|}{ Candida sp } \\
\hline 25 & $9.00 \pm 0.000$ & $10.50 \pm 0.707$ \\
\hline 50 & $11.50 \pm 0.707$ & $14.50 \pm 0.707^{*}$ \\
\hline 100 & $11.50 \pm 2.121$ & $13.50 \pm 2.121^{*}$ \\
\hline 250 & $11.50 \pm 0.707$ & $13.50 \pm 0.707^{*}$ \\
\hline 500 & $11.50 \pm 0.707$ & $14.00 \pm 1.414^{*}$ \\
\hline \multicolumn{3}{|c|}{ G. latifolium } \\
\hline
\end{tabular}

\begin{tabular}{|c|c|c|}
\hline Conc. $\mathrm{mg} / \mathrm{ml}$ & Ethyl acetate & Chloroform \\
\hline & \multicolumn{2}{|c|}{ A. flavus } \\
\hline 25 & $9.50 \pm 2.121$ & $11.00 \pm 1.414$ \\
\hline 50 & $9.50 \pm 0.707$ & $12.50 \pm 0.707$ \\
\hline 100 & $10.50 \pm 2.121$ & $13.00 \pm 2.828 *$ \\
\hline 250 & $13.00 \pm 1.414^{*}$ & $16.00 \pm 1.414 *$ \\
\hline \multirow[t]{2}{*}{500} & $14.50 \pm 0.707 *$ & $17.50 \pm 2.121 *$ \\
\hline & \multicolumn{2}{|c|}{ A. niger } \\
\hline 25 & $8.50 \pm 0.707$ & $11.00 \pm 1.414$ \\
\hline 50 & $10.00 \pm 1.414$ & $12.50 \pm 0.707$ \\
\hline 100 & $11.50 \pm 2.121^{*}$ & $14.00 \pm 0.000 *$ \\
\hline 250 & $12.50 \pm 2.121^{*}$ & $15.00 \pm 1.414 *$ \\
\hline \multirow[t]{2}{*}{500} & $13.00 \pm 1.414^{*}$ & $16.00 \pm 1.414 *$ \\
\hline & \multicolumn{2}{|c|}{ Trichoderma $\mathrm{sp}$} \\
\hline 25 & $9.00 \pm 1.414$ & $11.00 \pm 1.414$ \\
\hline 50 & $9.50 \pm 0.707$ & $13.00 \pm 1.414 *$ \\
\hline 100 & $11.50 \pm 0.707$ & $15.50 \pm 0.707 *$ \\
\hline 250 & $15.50 \pm 0.707^{*}$ & $18.50 \pm 0.707 *$ \\
\hline \multirow[t]{2}{*}{500} & $16.50 \pm 0.707^{*}$ & $20.50 \pm 0.707 *$ \\
\hline & \multicolumn{2}{|c|}{ Candida $\mathrm{sp}$} \\
\hline 25 & $7.50 \pm 0.707$ & $9.50 \pm 0.707$ \\
\hline 50 & $9.50 \pm 0.707$ & $12.00 \pm 1.414$ \\
\hline 100 & $10.50 \pm 0.707$ & $13.00 \pm 1.414^{*}$ \\
\hline 250 & $11.50 \pm 2.121$ & $14.00 \pm 1.414 *$ \\
\hline 500 & $13.00 \pm 1.414^{*}$ & $16.00 \pm 1.414 *$ \\
\hline \multicolumn{3}{|c|}{ Z. zanthoxyloides } \\
\hline
\end{tabular}

\subsection{Dose dependent activities}

The extent of antimicrobial activity of extract based on the zone of inhibition has been described as low (12-18 $\mathrm{mm})$, moderate $(19-22 \mathrm{~mm})$ and strong $(23-38 \mathrm{~mm})$ [47]. The dose response to plant extracts can be observed in Figure 1 and Table 2. At the lower doses $(25-50 \mathrm{mg} / \mathrm{ml})$, the extracts show low to moderate antimicrobial activities across the various plant extracts irrespective of the extraction solvent. The range of inhibition zones is between 7.5- $18.50 \mathrm{~mm}$. Noteworthy is the activity of ethyl acetate extract of Z. zythoxyliodes at this dose (18.50 mm; Fig. 1C) against E.coli. At the higher dosage, extracts showed moderate to high antibiosis with a range of 10.5 to $27.0 \mathrm{~mm}$. Noteworthy is the activities of Z. zythoxyloide's ethyl acetate extract against E.coli (Fig. 1C; $27.0 \mathrm{~mm}$ ), as well as its chloroform extract against $S$. pneumoniae $(21.50 \mathrm{~mm})$ (Fig. 1D) and Trichoderma $\mathrm{sp}$ (Table $2 ; 20.50)$. G. latifolium chloroform extract also exhibited appreciable activity against all tested microbes and its activity against $S$. pneumonia (Fig. 1D; $20.00 \mathrm{~mm}$ ) is remarkable. These results are qualitatively similar to those of Shaheed et al. [6] and Jones and Bridgeman [8] who observed increase in performances of herbal extracts at higher dosages against microbial pollutants of water.

\subsection{Comparative phytobiotic activities (with commercial antibiotics)}

The abilities of phytoactive extracts of plants materials investigated as compared with commercial antibiotics were investigated. Plant extracts investigated performed beyond the activities of commercial streptomycin, gentamycin and nystatin within selected concentration range investigated. Statistical analysis revealed notable significant differences from $25 \mathrm{mg} / \mathrm{ml}$ and above, but mostly at higher concentrations. The comparative antibiosis of commercial antibiotics, as well as minimum and maximum extract concentrations against tested microbes were presented in Tables 3 and 4. The results reveal that potent phytoactive formulations of the plant materials tested can be developed within the range researched in this work, and with better performance than available commercial antibiotics. The advent of such formulations as envisaged in this work may be the dawn of novel technology in achievement of the World Health Organisation (WHO) recommendation of zero faecal count/100 ml water sample [48] especially when developed for water disinfection. Potent antimicrobial 
activities of plant materials have been reported for different formulations such as antipsoriatic cream using different combinations of neem, sarsaparilla, bakuchi and daruhaldi which showed good antimicrobial and antiinflammatory results [49]; herbal ointment containing Aloe-vera, Azadirachta indica and Curcuma- longa showed good antimicrobial activity against the selected organisms microbes when compared to standard drugs [50]. In a study where polyherbal ointment was prepared using methanolic extracts of Azadirachta indica, Chromolaena odorata, Mimosa pudica, Samadera indica and evaluated for its antibacterial and antioxidant properties, the results showed better antibacterial properties [51]. These reported research findings support phytoactivities of plant materials as reported in this work. Herbal extracts of Ocimum samctum and Eucalyptus globules as anti-microbial agents were found to exhibit significant activity against E. coli, Pseudomonas aeuroginosa, Staphylococcus aureus, Bacillus subtilis, Sacchromyces cerevisiae as well as Candida albicans and were safer for human usage when compared to reference standards Ampicillin and Amphoterecin respectively [52].

Table 3: Comparative efficiency of plant extracts with commercial antibiotics (Streptomycin and Gentamycin) against tested bacteria

\begin{tabular}{|l|l|l|l|l|l|}
\cline { 2 - 6 } \multicolumn{1}{c|}{} & & \multicolumn{2}{c|}{ G. latifolium } & \multicolumn{2}{c|}{ Z. zanthoxyloides } \\
\cline { 2 - 6 } \multicolumn{1}{c|}{ aeruginosa } & STR & Ethyl acetate & Chloroform & Ethyl acetate & Chloroform \\
& Min & $7.50 \pm 0.707$ & $8.00 \pm 1.414$ & $7.00 \pm 0.000$ & $8.50 \pm 0.707$ \\
& Max & $10.00 \pm 1.414$ & $12.00 \pm 2.828$ & $8.00 \pm 0.000$ & $9.50 \pm 0.707$ \\
\hline Klebsiella sp & STR & $7.50 \pm 0.707$ & $8.00 \pm 0.000$ & $16.50 \pm 0.707^{+}$ & $19.00 \pm 1.414^{+}$ \\
& Min & $8.50 \pm 0.707$ & $9.50 \pm 0.707$ & $9.00 \pm 0.000$ & $7.50 \pm 0.707$ \\
& Max & $16.00 \pm 1.414^{+}$ & $18.00 \pm 1.414^{+}$ & $13.50 \pm 0.707^{+}$ & $10.00 \pm 1.414$ \\
\hline E.coli & STR & $7.50 \pm 0.707$ & $9.00 \pm 0.000$ & $8.50 \pm 0.000$ & $7.00 \pm 0.000$ \\
& Min & $10.50 \pm 0.707$ & $11.50 \pm 0.707$ & $15.50 \pm 0.707^{+}$ & $10.50 \pm 0.707$ \\
& Max & $15.50 \pm 0.707^{+}$ & $19.00 \pm 1.414^{+}$ & $27.00 \pm 0.707^{+}$ & $19.50 \pm 0.707^{+}$ \\
\hline S. pneumonia & GEN & $7.50 \pm 0.707$ & $9.00 \pm 0.000$ & $7.50 \pm 0.707$ & $8.50 \pm 0.707$ \\
& Min & $9.50 \pm 0.707$ & $11.50 \pm 0.707$ & $9.50 \pm 0.707$ & $12.50 \pm 0.707$ \\
& Max & $16.50 \pm 0.707^{+}$ & $20.00 \pm 0.000^{+}$ & $17.00 \pm 1.414^{+}$ & $21.50 \pm 2.121^{+}$ \\
\hline B. cereus & GEN & $7.50 \pm 0.707$ & $7.00 \pm 0.000$ & $7.00 \pm 0.000$ & $7.50 \pm 0.707$ \\
& Min & $8.50 \pm 0.707$ & $10.50 \pm 0.707$ & $8.50 \pm 0.707$ & $10.00 \pm 1.414$ \\
& Max & $12.00 \pm 1.414^{+}$ & $15.50 \pm 0.707^{+}$ & $13.502 .121^{+}$ & $17.00 \pm 1.414^{+}$ \\
\hline
\end{tabular}

+ values with significant difference from the standard; A, Streptomycin; B, Gentamycin; Min, minimum; Max, maximum

Table 4:Comparative efficiency of plant extracts with commercial antibiotic (nystatin) against tested fungi

\begin{tabular}{|l|l|l|l|ll|}
\cline { 2 - 6 } \multicolumn{1}{c|}{} & \multicolumn{3}{|l|}{ G. latifolium } & \multicolumn{2}{l|}{ Z. zanthoxyloides } \\
\cline { 2 - 6 } \multicolumn{1}{c|}{ A. flavus } & & Ethyl acetate & Chloroform & Ethyl acetate & Chloroform \\
& NIS & $7.00 \pm 0.000$ & $7.00 \pm 0.000$ & $7.50 \pm 0.707$ & $8.50 \pm 0.707$ \\
& Min & $7.50 \pm 0.707$ & $9.50 \pm 0.707$ & $9.50 \pm 2.121$ & $11.00 \pm 1.414$ \\
& Max & $12.50 \pm 0.707^{+}$ & $15.00 \pm 0.00^{+}$ & $14.50 \pm 0.707^{+}$ & $17.50 \pm 2.121^{+}$ \\
\hline A. niger & NIS & $7.50 \pm 0.707$ & $7.00 \pm 0.000$ & $7.00 \pm 0.000$ & $8.50 \pm 0.707$ \\
& Min & $9.50 \pm 0.707$ & $11.00 \pm 1.414$ & $8.50 \pm 0.707$ & $11.00 \pm 1.414$ \\
& Max & $14.50 \pm 0.707^{+}$ & $17.00 \pm 1.414^{+}$ & $13.00 \pm 1.414^{+}$ & $16.00 \pm 1.414^{+}$ \\
\hline Trichoderma sp & NIS & $7.00 \pm 0.000$ & $8.50 \pm 0.707$ & $7.50 \pm 0.707$ & $8.50 \pm 0.707$ \\
& Min & $8.50 \pm 0.707$ & $11.00 \pm 1.414$ & $9.00 \pm 1.414$ & $11.00 \pm 1.414$ \\
& Max & $13.50 \pm 0.707^{+}$ & $18.50 \pm 0.707^{+}$ & $16.50 \pm 0.707^{+}$ & $20.50 \pm 0.707^{+}$ \\
\hline Candida sp & NIS & $7.50 \pm 0.707$ & $8.50 \pm 0.707$ & $7.50 \pm 0.707$ & $8.50 \pm 0.707$ \\
& Min & $9.00 \pm 0.000$ & $10.50 \pm 0.707$ & $7.50 \pm 0.707$ & $9.50 \pm 0.707$ \\
& Max & $11.50 \pm 0.707$ & $14.00 \pm 1.414^{+}$ & $13.00 \pm 1.414^{+}$ & $16.00 \pm 1.414^{+}$ \\
\hline
\end{tabular}

+, values with significant difference; NIS, Nystatin, Min, minimum; Max, maximum

\subsection{Antibacterial activities}

The antibacterial activity of the extracts varied with respect to extraction solvents and susceptibility of microbial isolates increases with concentration of extract in solution (Figure 1). Noteworthy is the activities of the extracts against E.coli which is a widely accepted indicator of water pollution. The activities of extracts tested show effectiveness of all extracts against E.coli. Activity of the extracts on E.coli showed moderate to high antibiosis at concentrations of 50 to $500 \mathrm{mg} / \mathrm{ml}$. It is, however, notable that significant susceptibility was recorded at a concentration of $25 \mathrm{mg} / \mathrm{ml}$ of ethyl acetate extract of $Z$. zanthoxyloides which was the least concentration tested and may confirm possible potent antimicrobial activities of the investigated plants against groups of coliforms 
and microbial pathogens in water. The activities of the plants extracts against E.coli, Kelsiella sp and $P$. aeruginosa indicate the ability of these plant materials against a range of gram negative bacteria. For $P$. aeruginosa, susceptibility to plant extracts increases with concentration of the extracts in solution from 25 to $500 \mathrm{mg} / \mathrm{ml}$. At dosages of 25 and $50 \mathrm{mg} / \mathrm{ml}$, maximum values of 12.0 and $14.50 \mathrm{~mm}$ zones of inhibition respectively were observed when compared across all plant materials and extraction solvent use, which are low levels of susceptibility. The susceptibility of $P$. aeruginosa at this dose is, however, comparable to that of streptomycin. At doses of 100, 250 and $500 \mathrm{mg} / \mathrm{ml}$ maximum zones of inhibition recorded with respect to plant material and extraction solvents were 17.00, 17.50 and $19.00 \mathrm{~mm}$ respectively. Chloroform extracts of both plants seem to have effective antimicrobial action against $P$. aeruginosa. Considering Klebsiella sp., a low level susceptibility to concentrations of extracts at 25 and $50 \mathrm{mg} / \mathrm{ml}$ was observed. The minimum inhibition zones recorded at 25 and $50 \mathrm{mg} / \mathrm{ml}$ were $8.50 \mathrm{~mm}$ and $10.50 \mathrm{~mm}$ while the maximum zones were 10 and $13 \mathrm{~mm}$ respectively. These were low level antibiosis. However, the activity of chloroform extract of the two plants were significant at $50 \mathrm{mg} / \mathrm{ml}$ against Klebsiella $\mathrm{sp}$. All other concentrations of extracts irrespective of solvent material possessed significant antimicrobial activity against Klebsiela sp. Maximum zone was observed at $18.00 \mathrm{~mm}$ with chloroform extract of G. latifolium at $500 \mathrm{mg} / \mathrm{ml}$.

S. pneumonia and B. cereus are gram positive bacteria, the least antibiosis recorded for $S$. pneumoniae was 9.50 $\mathrm{mm}$ at concentration of $25 \mathrm{mg} / \mathrm{ml}$ of $G$. latifolium ethyl acetate extract while the optimum recorded was 20.00 $\mathrm{mm}$ (G. latifolium) and $21.50 \mathrm{~mm}$ (Z. zanthozyloides) from chloroform extract. Highest activity of plant extract against $B$. cereus was found to be $17.00 \mathrm{~mm}$ from chloroform extract of $Z$. zanthoxyloide at concentration of 500 $\mathrm{mg} / \mathrm{ml}$. These results also indicate the ability of extract to inhibit the growth of gram positive bacteria. The susceptibility of all tested microbial isolates to the plant extracts is therefore a clear indication that plants studied would be good candidates for disinfection product development.

\subsection{Antifungal activities}

Susceptibility of the fungal isolates to tested plant extracts were observed. The maximum antifungal activity of the extract recorded were in the order of $20.20 \mathrm{~mm}$ (Zanthoxylum chloroform extract against Trichoderma at $500 \mathrm{mg} / \mathrm{ml}$ ) $>17.50 \mathrm{~mm}$ (Zanthoxylum chloroform extract against A. flavus at $500 \mathrm{mg} / \mathrm{ml}$ ) $>17.00 \mathrm{~mm}$ (Gongronema chloroform extract against $A$. niger at $500 \mathrm{mg} / \mathrm{ml}$ ) $>16.00 \mathrm{~mm}$ (Zanthoxylum chloroform extract against Candida sp at $500 \mathrm{mg} / \mathrm{ml}$ ). Activities of extracts were significant from a concentration of $50 \mathrm{mg} / \mathrm{ml}$ to $500 \mathrm{mg} / \mathrm{ml}$ and show low to moderate antimicrobial activities (Table 2).

The overall results revealed that antimicrobial activities of the plant extracts are dose dependent with comparative activity greater than that of commercial antibiotics at the concentration of extracts tested. E.coli was the most susceptible microbial isolate tested and represents the potential of the extract against a group of coliform which are important indicators of microbial pollution in water. Other microbial isolates also recorded sensitivity to extracts tested at varying degrees. It was observed in these findings that microbes tested were most susceptible to chloroform extract of $Z$. zanthoxyloides and G. latifolium except for the activity of ethyl acetate extract of Z. zanthoxyloide against E.coli. Results of phytochemical screening of the extract also showed the varied presence of alkaloids, saponins, tannins, flavonoids, terpenoids and anthraquinones (Table 5). The observed trends of phytochemicals found in Z. zanthoxyloides for this work is in agreement with previous works carried out on same plant [53-55]. Plant constituents have been reported to possess antimicrobial properties $[56,57]$. Antimicrobial potency as reported in this work with a broad range of activity against gram-positive and gram-negative organisms is similar to that reported in the work of Adegbolagun and Olukemi [58] when reporting the activity of $Z$. zanthxyloides against selected microbial isolates. Optimum antimicrobial inhibition reported in this work is, however, greater than that reported by Adegbolagun and Olukemi [58] for Bacillus, E. coli, and $P$. aeruginosa, which may be attributed to the concentrations of extract used. Adesina [54] has reported the demonstration of antibacterial activity by many species of Zanthoxylum against both "gram-positive and gram-negative" microorganisms, although aqueous extracts of Zanthoxylum have been shown to be less effective against microbial sample of $P$. aeruginosa and E. coli $[59,60]$. Stem and root bark extracts from $Z$. zanthoxyloides have also been reported to have a higher activity against bacteria implicated in periodontal diseases [61]. In the work of Olila et al. [62], there was no antimicrobial activity reported from Zanthoxylum chalybeum against E. coli and Candida albicans tested. This was attributed to low dosage and solubility of extract in extraction solvent used [63]. 
Table 5: Phytochemical compositions of G. latifolium and Z. zanthoxyloides

\begin{tabular}{ccccc}
\hline Analysis & \multicolumn{2}{c}{ G. latifolium } & \multicolumn{2}{c}{ Z. zanthoxyloides } \\
& Ethyl acetate & Chloroform & Ethyl acetate & Chloroform \\
\hline Saponins & Absent & Present & Present & Absent \\
Tannins & Present & Present & Absent & Absent \\
Reducing Sugars & Absent & Absent & Absent & Absent \\
Alkaloids & Present & Present & Present & Present \\
Flavonoids & Absent & Present & Present & Present \\
Terpenoids & Absent & Absent & Present & Present \\
Phlobatannins & Absent & Absent & Absent & Absent \\
Steroids & Absent & Absent & Absent & Absent \\
Anthraquinones & Absent & Absent & Present & Absent \\
\hline
\end{tabular}

The doses of antimicrobial samples used in this work were found to be effective in the treatment of the microbial isolates investigated with effectiveness against all bacterial and fungal isolates. Phytochemical products that produce minimum inhibitory concentrations (MIC) in the range $100-1000 \mathrm{mg} \mathrm{mL}^{-1}$ in in vitro susceptibility tests have been classified as antimicrobials [64].

The activity of $G$. latifolium as reported in this work is also similar to other reports on the activity of $G$. latifolium extracts to inhibit different microbes $[23,65,66]$. The presence of saponins and flavonoids in $G$. latifolium have been attributed to its antimicrobial efficacy [22,67]. In a similar manner to the findings of this study, Staphylococcus sp., Shigella sp., Salmonella sp., Klebsiella Pneumonia, Pseudomonas sp., Escherichia coli and Onchrobactrum anthropi were all inhibited at $100 \mathrm{mg} / \mathrm{ml}$ in Adeleye and Omadime [68]. The presence of essential oil was attributed to high antimicrobial and fungicidal effects against all the tested organisms including Candida albicans. Zones of inhibition ranged between $7.5 \mathrm{~mm}$ for Pseudomonas aeruginosa to $11.25 \mathrm{~mm}$ for Shigella flexneri, respectively. However, activity of extracts were comparatively lesser than that of commercial antibiotics at the concentration tested suggesting the inefficiency of active ingredient present at the concentration of extract tested which was not the case in this work. The extracts tested over the range of concentrations considered showed improved antimicrobial activities over all antibiotics used, mostly, with significant differences

\section{Conclusion}

A major conclusion is that plant samples tested revealed potent antimicrobial activities which significantly compared with commercial antibiotics at the concentration of extracts tested. Very strong potency of the plant extract was observed against E. coli; a water pollution indicator. High amount of crude extract needed in this work to attain effective inhibition of microbial isolates can be reduced by further identification of active ingredients and subsequent purification. Formulation and development of active component of G. latifolium and Z. zanthoxyloides into biotechnological products for water purification is recommended.

Acknowledgement: Adeeyo A.O acknowledges Prof J.O Odiyo and Prof T.A.M Msagati for the research support provided.

Author Contributions: A.O Adeeyo and J.O Odiyo conceived this work, T.A.M Msagati assisted in interpretation of data.

Conflicts of Interest: The authors declare no conflict of interest. 


\section{References}

[1]. Megersa, M.; Beyene, A.; Ambelu, A.; Woldeab, B. The use of indigenous plants for drinking water treatment in developing countries: A review. J Bio Env Sci 2014, 5, 269-281.

[2]. W.H.O (World Health Organization). The right to water. Geneva: WHO Library Cataloguing-in publication data. 2003.

[3]. Skandhan, K.P.; Amith, S.; Karunatilake, L.P.; Anvi, K.P.; Singh, K. Water purification prescribed in Aryurveda. AYU 2011, 32, 448-450.

[4]. Jadhav, A.S. Advancement in drinking water treatments from ancient time. Int. J. Sci. Environ. Technol. 2014,3,1415-1418.

[5]. Hyung, H.; Kim, J.H. Dispersion of C 60 in natural water and removal by conventional drinking water treatment processes. Water Res. 2009,43,2463-2470.

[6]. Shaheed, A.; Templeton, M.R.; Matthews, R.L.; Tripathi, S.K.; Bhattarai, K. Disinfection of waterborne coliform bacteria using Luffa cylindrica fruit and seed extracts. Environ. Technol. 2009,30,1435-1440.

[7]. Dubreuil, J.D. Antibacterial and antidiarrheal activities of plant products against enterotoxinogenic Escherichia coli. Toxins 2013, 5, 2009-2041.

[8]. Jones, A.N.; Bridgeman, J. Disinfection ability of hibiscus seeds in water treatment. P I Civil Eng. 2017 Dx.doi.org/10.1680/Jwama.16.00106.

[9]. W.H.O (World Health Organization) Guidelines for Drinking Water Quality, First Addendum to 3rd Edition Recommendations 1. 2006 (Accessed 22.02.12). http://www.Who.int/watersanitationhealth/dwq/gd wq0506.pdf

[10].W.H.O (World Health Organization) The World Health Report - a Safer Future: Global Public Health Security in the 21 st Century, Geneva. 2007.

[11].W.H.O (World Health Organization) Evaluating household water treatment options: Health-based targets and microbiological performance specifications, Geneva. 2011.

[12]. Gaur, R.D. Flora of the District Garhwal North West Himalaya: With Ethnobotanical Notes. TransMedia, Srinagar, 1999, p. 811.

[13]. Negi, J.S.; Bisht, V.S.; Bhandari, A.K.; Singh, P.; Sundriyal, R.C. Chemical constituents and biological activities of the genus Zanthoxylum: A review. Afr J Pure Appl Chem 2011, 5, 412-416

[14]. Nacoulma, O. Plantes médicinales et pratiques médicales traditionnelles au Burkina Faso Cas du plateau central. TOME II. Thèse d'Etat. Univ Ouaga 1996, 332p.

[15]. Arbonnier, M. Trees, shrubs and lianas of West African dry zones. CIRAD, Margraf Publishers Gmbh, MNHN, Paris, France 2004, 573 pp.

[16]. Ngassoum, M.B.; Essia-ngang, J.J.; Tatsadjieu, L.N. Antimicrobial study of essential oils of Ocimum gratissimum leaves and Zanthoxylum xanthoxyloides fruits from Cameroon. Fitoterapia 2003, 74, $284-287$.

[17]. Ouattara, B.; Angenot, L.; Guissou, P.; Fondu, P.; Dubois, J.; Frédérich, M.; Jansen, O.; van Heugen J.C.; Wauters, J.N.; Tits, M. LC/MS/NMR analysis of isomeric divanilloylquinic acids from the root bark of Fagara zanthoxyloides Lam. Phytochemistry 2004, 65,1145-51.

[18]. Fogang, H.P.; Tapondjou, L.; Womeni, H.; Quassinti, L.; Bramucci, M.; Vitali, L.A.; Petrelli, D.; Lupidi, G.; Maggi, F.; Papa, F.; Vittori, S.; Barboni, L. Characterization and biological activity of essential oils from fruits of Zanthoxylum xanthoxyloides Lam. and Z. Leprieurii Guill. \& Perr., two culinary plants from Cameroon. Flavour Fragr J. 2012, 27, 171-179.

[19]. Wouatsa, V.N.; Misra, L.; Kumar, S.; Prakash, O.; Khan, F.; Tchoumbougnang, F.; Venkatesh, R.K. Aromatase and glycosyl transferase inhibiting acridone alkaloids from fruits of Cameroonian Zanthoxylum species. Chem Cent J 2013,7,125. 
[20]. Okafor, J.C. Conservation and the use of traditional vegetables from woody forest species in southeastern Nigeria. In the International Plant Genetic Resources Institute workshop on Genetic Resource of Traditional Vegetables in Africa Conservation and Use. ICRAF - HQ, Nairobi, Kenya 2005.

[21]. Schneider, C.; Rotscheidt, K.; Breitmaier, E. 4 new pregnane glycosides from Gongronema latifolium (Asckepiadaceae). Liebigs Annalen Der Chemie 1993, 10, 1057-1062.

[22]. Morebise, O.; Fafunso, M.A. Antimicrobial and phytotoxic activities of saponin extracts from medicinal plants. Biokemistri 1998, 8, 69-77.

[23]. Morebise, O.; Fafunso, M.A.; Makinde, J.M.; Olajide, O.A.; Awe, E.O. Antiinflammatory property of Gongronema latifolium. Phytother. Res 2002, 16, S75-S77. doi:10,1002/ptr.784.

[24]. Essien, J.P.; Ebong, G.A.; Akpan, E.J. Antioxidant and antitussive properties of Gongronema latifolium leaves used locally for the treatment of fowl cough in Nigeria. J. Appl. Sci. Environ. Manage 2007, 11, 47-50.

[25]. Ugochukwu, N.H.; Babady, N.E. Antihyperglycemic effect of aqueous and ethanolic extracts of Gongronema latifolium leaves on glucose and glycogen metabolism in livers of normal and streptozotocininduced diabetic rats. Life Sci 2003a,73,1925-1938.

[26]. Ugochukwu, N.H,; Babady, N.E.; Cobourne, M.; Gasset, S.R. The effect of Gongronema latifolium leaf extract on serum lipid profile and oxidative stress of hepatocytes of diabetic rats. J Biosci 2003b,28, 1-5.

[27]. Ogundipe, O.O.; Moody, J.O.; Akinyemi, T.O.; Raman, A. Hypoglycemic potentials of methanolic extracts of selected plant foods in alloxanized mice. Plant Foods Hum. Nutr 2003,58,1-7. [doi:10.1023/B:QUAL.0000040321. 56831.c4].

[28]. Akuodor, G.C.; Idris-Usman, M.S.; Mbah, C.C.; Megwas, U.A.; Akpan, J.L.; Ugwu, T.C.; Okoroafor, D.O.; Osunkwo, U.A. Studies on anti ulcer, analgesic and antipyretic properties of the ethanolic leaf extract of Gongronema latifolium in rodents. Afr. J. Biotechnol. 2010, 9, 2316-2321.

[29]. Eja, S.M.; Salwei, P.; Jaboski, W. Chemical composition and antibacterial activity of Ocimum gratissimum. Pharm 2011, 30, 723-834.

[30]. Oshodi, A.A.; Amoo, I.A.; Eleyinmi, A.F. Antimicrobial activity of aqueous extracts of Vernonia amygdalina, Garcinia kola and Gongronema latifolium and their blends on some beer spoilage organisms. Tech. Q. Master Brew. Assoc Am 2004, 41, 398-402.

[31]. Nenaah, E.G.; Ahmed, M.E. Antimicrobial Activity of Effects and Latex of Caiotropis procera (Ait) and synergistic Effect with Reference to Antimicrobials Research. J Med Plant 2011,5, 706- 716.

[32]. Ndabigengesere, A.; Narasiah, K.S.; Talbot, B.G. Active agents and mechanisms of coagulation of turbid water using Moringa oleifera. Water Res 1995,29,703-710.

[33]. Gebremichael, K.A.; Gunaratna, K.R.; Henriksson, H.; Harry, B.; Gunnel, D. A simple purification and activity assay of the coagulant protein from Moringa oleifera seed. Water Res 2005, 39, 2338- 2344.

[34]. Shilpa, B.S.; Akanksha, K.; Girish, P. Evaluation of Cactus and Hyacinth Bean peels as natural coagulants. Int J Chem Eng 2012,3,187-191.

[35]. Zhang, J.; Fang, Z.; Yuhong, L.; Hong, Y. A preliminary study on cactus as coagulant in water treatment. Process Biochem 2006, 41, 730-733.

[36]. Choubey, S.; Rajput, S.K.; Bapat, K.N. Comparison of some natural coagulants bioremediation. Int J Technol Adv Eng 2012, 2, 429- 434.

[37]. Yongabi, K.A.; Lewis, D.M.; Harris, P.L. Application of phytodisinfectants in water purification in rural Cameroon. Afr J Microbiol Res 2011a,5, 628-635.

[38]. Yongabi, K.A.; Lewis, D.M.; Harris, P.L. Indigenous plant based coagulants/disinfectants and sand filter media for surface water treatment in Bamenda, Cameroon. Afr J Biotechnol 2011b,10,8625-8629. 
[39]. Marobhe, N.J.; Gunaratna, R.K. Effect of coagulant protein from Parkinsonia aculeata and Citrus juice on bacteria isolated from Ruvu River in Tanzania. Int J Appl Sci Eng Res 2012,1, 714-724.

[40]. Pritchard, M.; Mkandawire, T.; Edmondson, A.; O’Neill, J.G.; Kululanga, G. Potential of using plant extracts for purification of shallow well water in Malawi. J Phys Chem Earth 2009, 34, 799-805.

[41]. Vara, S. Screening and evaluation of innate coagulants for water treatment: a sustainable approach. Int J Energy Environ Eng 2012, 3, 1-29.

[42]. Kihampa, C.; Mwegoha, W.J.S.; Kaseva, M.E.; Marobhe, N. Performance of Solanum incunum L. as natural coagulant and disinfectant for drinking water. Afr J Environ Sci Technol 2011,5, 867-872.

[43]. Sciban, M.; Mirjana, G.A.; Mile, T.K. Extraction and partial purification of coagulation active components from common bean seeds. Acta Periodica Technologica 2006, 37, 37-43.

[44]. Lateef, A.; Adeeyo, A.O. Green synthesis and antibacterial activities of silver nanoparticles using extracellular laccase of Lentinus edodes. Not Sci Biol 2015, 7, 405-11. [http://dx.doi.org/10.15835/nsb.7.4.9643].

[45]. Harborne, J.B. Phytochemical Methods, A Guide to Modern Techniques of Plant analysis. 2nd ed. London: Chapman and Hall 1998, pp. 54-84.

[46]. Adeeyo, A.O.; Odiyo, J.; Odelade, K. Chemical profiling and antimicrobial properties of phyto-active extracts from Terminalia glaucescens stem against water microbial contaminants. Open Biotechnol J 2018, 12,317.

[47]. Ahmad, I.; Zaiba-Beg, A.Z.; Mehmood, Z. Antimicrobial potency of selected medicinal plants with special interest in activity against phytopathogenic fungi. Indian Vet med J 1999, 23, 299-306.

[48]. W.H.O (World Health Organization) Guidelines for Drinking-Water Quality. Vol. 2: Health Criteria and Other Supporting Information: Addendum. WHO, Geneva, Switzerland. 1998.

[49]. Mundada, A.S.; Mahajan, M.S.; Gangurde, H.H.; Borkar, V.S.; Gulecha, V.S.; Khandare, R.A. Formulation and evaluation of polyherbal antipsoriatic cream. Pharmacologyonline 2009, 2, 1185-1191.

[50]. Pandey, A,; Jagtap, J.V.; Patil, A.A.; Joshi, R.N.; Kuchekar, B.S. Formulation and evaluation of antibacterial and anti-fungal activity of a herbal ointment containing Aloe-vera, Azadirachta indica and Curcumalonga. J Chem Pharm Res 2010,2,182-186.

[51]. Rajasree, P.H.; Vishwanad, V.; Cherian, M.; Eldhose, J.; Singh, R. Formulation and evaluation of antiseptic polyherbal ointment. Int J Pharm and Life Sci 2012, 3, 2021-2031.

[52]. Wani, N.S.; Bhalerao, A.K.; Ranaware, V.P.; Zanje, R. Formulation and Evaluation of Herbal Sanitizer. Int J PharmTech Res 2013,5,40-43.

[53]. Adesina, S.K. Further novel constituents of Zanthoxylum zanthoxyloides root and pericarp. J. Nat. Prod $1986,69,715-716$.

[54]. Adesina, S.K. The Nigerian Zanthoxylum: Chemical and biological values. Afri J Trad Compl Med 2005, 2,282-301.

[55], Chaaib, K.F. Phytochemical investigation of an African chewing stick, Zanthoxylum zanthoxyloides (Lam) Zepernick and Timler. Doctorate Thesis, University of Lausanne 2004, pp. 11-31.

[56]. Iwu, M.W.; Duncan, A.R.; Okunji, C.O. New Antimicrobial of plant origin. In: J. Janick (ed). Perspectives on new crops and new issues. ASHS Press, Alexandria, V.A 1999, pp. $457-462$.

[57]. Banso, A.; Adeyemo, S. Phytochemical screening and antimalarial assessment of Abutilon mauritianum, Bacopamonnifera and Datura stramonium. Biokemistri 2006,18, 39 - 44.

[58]. Adegbolagun, O.M.; Olukemi, O.O. Effect of light irradiation on the antimicrobial activity of Zanthoxylum zanthoxyloides (lam) methanolic extract. Afr J Pharm Pharmacol 2010, 4, 145-150. 
[59]. Ndukwe, K.C.; Okeke, I.N.; Lamikanra, A.; Adesina, S.K.; Aboderin, O. Antibacterial activity of aqueous extracts of selected chewing sticks. J Contemp Dent Pract 2005, 8, 1-7.

[60]. Adebiyi, A.O.; Koekemoer, T.; Adebiyi, A.P.; Smith, N.; Baxter, E.; Naude, R.J.; van de Venter, M. Antimicrobial and antioxidant activities of crude extracts of two Nigerian chewing sticks. Pharm Biol 2009, 47, 320-327, DOI: 10.1080/13880200902748460

[61]. Taiwo, O.; Xu, H.; Lee, S.F. Antibacterial activities of extracts form Nigerian chewing sticks. Phytother. Res 1999,13,675-679.

[62]. Olila, D.; Odyek, O.; Opuda-Asibo, J. Antibacterial and antifungal activities of extract of Zanthoxylum chalybeum and Warburgia ugandensis, Ugandan medicinal plants. Afr J Health Sci 2001, 1, 66-72.

[63]. Nair, R.; Chanda, S. Activity of some medicinal plants against certain pathogenic bacterial strains. Ind J Pharmacol 2006, 38,142-144.

[64]. Abreu, A.C.; McBain, A.J.; Simoes, M. Plants as sources of new antimicrobials and resistance-modifying agents. Nat Prod Rep 2012, 29, 1007-1021. DOI: 10.1039/c2np20035j.

[65]. Ugochukwu, N.H.; Babady, N.E. Antioxidant effects of Gongronema latifolium in hepatocytes insulin dependent diabetes mellitus Filoterapia 2002,73,612 -618.

[66]. Farombi, E.O. African indigenous plants with chemotherapeutic potentials and biotechnological approach to the production of bioactive prophylactic agents. Afr J Biotechnol 2003, 2, 662-671.

[67]. Hernández, N.E.; Tereschuk, M.L.; Abdala, L.R. Antimicrobial activity of flavonoids in medicinal plants from Tafi del Valle (Tucuman, Argentina). J Ethnopharmacol 2000,73, 317-322. [doi:10.1016/S03788741(00)00295-6.

[68]. Adeleye, I.A.; Omadime, M.E.; Daniels, F.V. Antimicrobial Activity of Essential Oil and Extracts of Gongronema latifolium Decne on Bacterial Isolates from Blood Stream of HIV Infected Patients. J Pharmacol and Toxicol 2011, 6, 312-320. 